\title{
Profil Hematologik Berdasarkan Jenis Plasmodium pada Pasien Malaria di Beberapa Rumah Sakit di Kota Padang
}

\author{
Siti Umi Kustiah ${ }^{1}$, Adrial ${ }^{2}$, Mohamad Reza ${ }^{3}$
}

\begin{abstract}
Abstrak
Spesies Plasmodium (P) yang banyak dijumpai di Sumatera Barat adalah P. falciparum dan $P$. vivax. Komplikasi yang paling umum terjadi pada infeksi malaria adalah perubahan hematologi. Infeksi $P$. falciparum lebih sering menimbulkan komplikasi tersebut dibandingkan infeksi $P$. vivax. Tujuan: Mengetahui perbedaan gambaran hematologik terutama hemoglobin, leukosit, dan trombosit pada pasien malaria berdasarkan jenis Plasmodium. Metode: Penelitian ini merupakan studi analitik dengan metode cross sectional. Data berasal dari rekam medik pasien malaria rawat inap di RSUP Dr. M. Djamil dan RSUD Dr. Rasidin Padang yang dilakukan pada bulan Desember 2017 sampai Januari 2018. Pengambilan sampel menggunakan teknik total sampling. Data dianalisis secara univariat dan bivariat menggunakan uji Independent $t$-test. Hasil: Dari 60 subjek penelitian, 51 orang (85\%) terinfeksi $P$. vivax, 8 orang $(13,3 \%)$ terinfeksi $P$. falciparum, dan 1 orang $(1,7 \%)$ mengalami infeksi campuran. Berdasarkan distribusi data demografi, frekuensi tertinggi pada laki-laki (53,3\%), dan sebagian besar berumur 15-35 tahun. Hasil uji-t terhadap nilai hemoglobin $(p=0,000)$ menunjukan terdapat perbedaan yang signifikan antara kedua jenis spesies Plasmodium. Berdasarkan jumlah leukosit $(p=0,198)$ dan trombosit $(p=0,242)$. Simpulan: Tidak terdapat perbedaan yang signifikan antara kedua jenis spesies Plasmodium.
\end{abstract}

Kata kunci: malaria, plasmodium falciparum, plasmodium vivax, hemoglobin, leukosit, trombosit

\begin{abstract}
In West Sumatera, Plasmodium falciparum and Plasmodium vivax are the species commonly found. The most common complication in malaria are caused by hematological change. Compare to P. vivax, P. falciparum is more often contribute to the malaria complication. Objectives:To observed hematological profile (especially hemoglobin, leukocyte, and thrombocyte) of malaria patients based on the Plasmodium's type. Methods: This was a analytical approach with cross sectional method. This study was conducted at RSUP Dr. M. Djamil and RSUD Dr. Rasidin Padang from December two thousand seventeen until January two thousand eighteen. Data sampling is taken by using total sampling technique. Univariate and bivariate are used for the data analysis with T-test Independent. Results: From sixty patients, fifty one patients (eighty five percent) had $P$. vivax infection and eight patients (thirteen point three percent) had $P$. falciparum infection while one patient (one point seven percent) had mixed $P$. vivax and $P$. falciparum infection. Based on the demographic data distributions, male patients were present the highest frequency (fifty three point three percent) and most of them are from fifteen until thirty five years old. T-test result on hemoglobin $(p=0,000)$ shows significant difference between $P$. vivax and $P$. falciparum. While using the number of leukocytes $(p=0,198)$ and thrombocyte $(p=0,242)$ for the test. Conclusion: There is no significant difference between both Plasmodium species.
\end{abstract}

Keywords: malaria, plasmodium falciparum, plasmodium vivax, hemoglobin, leukocyte, thrombocyte

Affiliasi penulis: 1. Prodi Pendidikan Dokter, Fakultas Kedokteran, Universitas Andalas, Padang, Indonesia. 2. Bagian Parasitologi, Fakultas Kedokteran, Universitas Andalas, Padang, Indonesia. 3. Bagian Biologi, Fakultas Kedokteran, Universitas Andalas, Padang, Indonesia.

Korespondensi: Mohamad Reza, Email: reza@med.unand.ac.id 


\section{PENDAHULUAN}

Malaria adalah penyakit infeksi disebabkan oleh parasit dari genus Plasmodium yang menyerang sel eritrosit ditandai dengan gejala berupa demam, menggigil, anemia, dan splenomegali dalam kondisi akut ataupun kronis yang ditularkan ke manusia melalui gigitan nyamuk Anopheles betina yang terinfeksi. ${ }^{1}$ Ada lima spesies Plasmodium yang dapat menyebabkan malaria pada manusia diantaranya $P$. falciparum, $P$. vivax, $P$. ovale, $P$. malariae, dan P. knowlesi. ${ }^{1,2}$

Malaria masih menjadi masalah kesehatan global terutama di kawasan tropis dan subtropis negara berkembang sampai saat ini. World Malaria Report 2015 menyatakan bahwa penyakit malaria telah menyerang 106 negara di dunia. ${ }^{3}$ Tahun 2016 ditemukan 216 juta kasus baru malaria dan 445.000 kematian. Wilayah Afrika menyumbang sebagian besar kasus malaria global $(90 \%)$, diikuti oleh wilayah Asia Tenggara (7\%), dan Mediterania Timur (2\%). Angka kematian akibat malaria tahun 2015 di wilayah Asia paling tinggi berada di India dengan jumlah 384 jiwa, sedangkan Indonesia berada pada posisi kedua dengan jumlah 157 jiwa. $^{4}$ Menurut WHO, angka morbiditas dan mortalitas akibat malaria cenderung menurun pada periode 2005- 2015. Meskipun demikian, masih ada lebih kurang 3,2 milyar jiwa atau hampir separuh penduduk dunia berisiko tertular penyakit malaria. $^{5}$

Data DKK Padang memperlihatkan 155 kasus malaria positif pada tahun 2015. Puskesmas yang paling tinggi kasusnya adalah puskesmas Belimbing dengan 37 kasus, sedangkan yang paling rendah adalah puskesmas Seberang Padang dengan tidak ada kasus malaria baik klinis maupun dari pemeriksaan sediaan darah. ${ }^{6}$

Perubahan hematologi merupakan komplikasi yang paling umum terjadi pada infeksi malaria. Kelainan hematologi pada malaria yang telah dilaporkan adalah anemia, trombositopenia, dan leukopenia hingga leukositosis. ${ }^{7}$ Beberapa mekanisme terjadinya anemia pada penyakit malaria yaitu penghancuran eritrosit yang mengandung parasit, diseritropoesis (gangguan dalam pembentukan eritrosit karena depresi eritropoesis dalam sumsum tulang), hemolisis oleh proses kompleks imun yang dimediasi komplemen pada eritrosit yang tidak terinfeksi, dan pengaruh sitokin. ${ }^{1,8}$ Anemia terutama tampak jelas pada malaria falciparum dan malaria kronis dengan penghancuran eritrosit yang cepat dan hebat. $^{1}$

Jumlah trombosit normal di dalam darah adalah 150.000 - 450.000 sel/ $\mu \mathrm{l}$. Trombositopenia adalah penurunan jumlah trombosit menjadi $<150.000 \mathrm{sel} / \mu \mathrm{l}$ di dalam darah. ${ }^{9}$ Infeksi malaria menyebabkan abnormalitas pada struktur dan fungsi trombosit. Penurunan jumlah trombosit pada malaria berkaitan dengan berbagai penyebab diantaranya lisis yang dimediasi imun, sekuestrasi pada limpa, gangguan pada sumsum tulang dan fagositosis oleh makrofag. ${ }^{10}$

Leukosit dalam darah rata-rata berjumlah 4.000 - $11.000 \mathrm{sel} / \mu \mathrm{l}$. Peningkatan jumlah leukosit melewati batas tertinggi disebut leukositosis dan penurunan di bawah batas terendah leukopenia. ${ }^{11}$

Penelitian di rumah sakit Surat Gujarat, India tahun 2013 didapatkan dari 1445 pasien malaria, $841(59 \%)$ terinfeksi $P$. falciparum, 591(41\%) terinfeksi P. vivax, dan $13(0.9 \%)$ infeksi campuran. Hemoglobin rata-rata pada pasien malaria falciparum adalah 9,78 g/dl, sedangkan pada malaria vivax adalah 10,26 g/dl. Pasien malaria yang memiliki jumlah trombosit normal dilaporkan sebanyak 18\%, sedangkan yang mengalami trombositopenia sebanyak $41 \%$ pada malaria vivax dan $59 \%$ pada malaria falciparum. ${ }^{7}$

Penelitian di RSK Lindimara, Sumba Timur tahun 2017 diperoleh gambaran kadar hemoglobin pada pasien tidak menunjukkan perbedaan yang signifikan antara pasien dengan infeksi $P$. falcifarum dan $P$. vivax. ${ }^{12}$

Penelitian ini bertujuan untuk melihat perbandingan profil hematologik (kadar hemoglobin, jumlah trombosit, dan jumlah leukosit) pada pasien malaria falciparum dengan malaria vivax di beberapa rumah sakit di kota Padang, yaitu RSUP Dr. M. Djamil dan RSUD Dr. Rasidin Padang.

\section{METODE}

Jenis penelitian ini adalah analitik
observasional dengan desain cross sectional.
Penelitian ini dilakukan di bagian Rekam Medik RSUD


Dr. Rasidin dan RSUP Dr. M. Djamil Padang. Penelitian ini dilaksanakan selama 2 bulan. Populasi penelitian ini adalah seluruh data rekam medik pasien malaria di bagian rekam medik RSUD Dr. Rasidin dan RSUP Dr. M. Djamil Padang dari tahun 2015-2017. Sampel penelitian ini adalah semua populasi yang memenuhi kriteria Inklusi dan ekslusi.

Kriteria inklusi adalah responden dengan malaria yang memiliki data rekam medik lengkap meliputi, umur, jenis kelamin, spesies penyebab, kadar hemoglobin, leukosit, trombosit, responden yang berusia $\geq 15$ tahun. Kriteria ekslusi adalah responden telah mengalami anemia sebelum terserang penyakit malaria, responden mengalami riwayat gangguan pada sistem hematologi, responden dalam kondisi hamil, dan memiliki kelainan genetik pada hemoglobin.

Teknik pengambilan sampel adalah secara total sampling. Data akan disajikan dalam bentuk tabel dengan menggunakan analisis univariat dan analisis bivariat. Analisis univariat digunakan untuk mengetahui kadar hemoglobin, jumlah trombosit, dan jumlah leukosit pasien malaria yang disajikan dalam bentuk tabel distribusi frekuensi. Analisis bivariat yang dilakukan untuk melihat perbedaan kadar hemoglobin, jumlah trombosit, dan jumlah leukosit antara $P$. falciparum dan $P$. vivax dengan menggunakan uji Independent t-test jika distribusi data normal dan dikatakan bermakna bila $p<0,05$. Jika distribusi data tidak normal dilakukan transformasi data atau dapat juga menggunakan uji non parametrik seperti uji Mann-Whitney.

\section{HASIL}

Hasil data rekam medik yang dikumpulkan dari Instalasi Rekam Medik RSUP Dr. M. Djamil dan RSUD Dr. Rasidin Padang periode 2015-2017 diperoleh sebanyak 60 orang sebagai sampel penelitian. Sampel penelitian di RSUP Dr. M. Djamil berjumlah 27 orang, sedangkan di RSUD Dr. Rasidin Padang 33 orang.

\section{Karakteristik Responden}

Tabel 1. Karakteristik pasien malaria di RSUD Dr. Rasidin Padang

\begin{tabular}{lrr}
\hline Karakteristik & $\begin{array}{c}\text { Frekuensi } \\
\text { (n) }\end{array}$ & $\begin{array}{c}\text { Persentase } \\
\text { (\%) }\end{array}$ \\
\hline Usia & 10 & 30,3 \\
$15-25$ & 6 & 18,2 \\
$26-35$ & 5 & 15,2 \\
$36-45$ & 8 & 24,2 \\
$46-55$ & 1 & 3 \\
$56-65$ & 3 & 9,1 \\
$>65$ & & \\
Jenis Kelamin & 16 & 48,5 \\
Laki-laki & 17 & 51,5 \\
Perempuan & & \\
Spesies Penyebab & 1 & 3 \\
P. falciparum & 32 & 97 \\
$P$. vivax & 0 & 0 \\
$P$. ovale & 0 & 0 \\
$P$. malariae & 0 & 0 \\
$P$. knowlesi & 0 & 0 \\
Infeksi campuran & & \\
\hline & &
\end{tabular}

Tabel 1 menunjukkan karakteristik pasien malaria di bagian rawat inap IImu Penyakit Dalam RSUD Dr. Rasidin Padang periode 2015- 2017 berdasarkan usia, jenis kelamin, dan spesies penyebab malaria. Pasien malaria terbanyak adalah perempuan sebanyak 17 orang (51,5\%). Pasien malaria terbanyak berdasarkan karakteristik usia terdapat pada kelompok usia 15-25 tahun sebanyak 10 orang $(30,3 \%)$. Spesies terbanyak yang menyebabkan kasus malaria adalah $P$. vivax sebesar 97\% dan diikuti oleh $P$. falciparum sebesar $3 \%$. $P$. ovale, $P$. malariae, $P$. knowlesi, dan infeksi campuran tidak ada ditemukan.

Hasil dari Tabel 2 menunjukkan karakteristik pasien malaria di bagian rawat inap Ilmu Penyakit Dalam RSUP Dr. M. Djamil Padang periode 2015 2017 berdasarkan usia, jenis kelamin, dan spesies. 
Tabel 2. Karakteristik Pasien Malaria di RSUP Dr. M. Djamil Padang

\begin{tabular}{crr}
\hline Karakteristik & Frekuensi (n) & Persentase (\%) \\
\hline Usia & & \\
$15-25$ & 10 & 18,5 \\
$26-35$ & 6 & 33,3 \\
$36-45$ & 8 & 14,8 \\
$46-55$ & 1 & 11,1 \\
$56-65$ & 3 & 18,5 \\
$>65$ & & 3,7 \\
Jenis Kelamin & 16 & \\
Laki-laki & 11 & 59,3 \\
Perempuan & & 40,7 \\
Spesies Penyebab & 7 & \\
P. falciparum & 19 & 25,9 \\
P. vivax & 0 & 70,4 \\
P. ovale & 0 & 0 \\
P. malariae & 0 & 0 \\
P. knowlesi & 1 & 3,7 \\
Infeksi campuran & & \\
\hline
\end{tabular}

Pasien malaria terbanyak adalah laki-laki sebanyak 16 orang (59,3\%). Pasien malaria terbanyak berdasarkan karakteristik usia terdapat pada kelompok usia 26-35 tahun sebanyak 9 orang (33,3\%). Spesies terbanyak yang menyebabkan kasus malaria adalah $P$.vivax sebesar $70,4 \%$ dan diikuti oleh $P$. falciparum sebesar $25,9 \%$. Infeksi campuran ditemukan sebesar $3,7 \%$, sedangkan $P$. ovale, P. malariae, dan $P$. knowlesi tidak ada ditemukan.
Karakteristik Status Hematologis Pasien Malaria Vivax dan Malaria Falciparum

Tabel 3. Karakteristik Status Hematologis Pasien Malaria Vivax dan Malaria Falciparum di RSUD Dr. Rasidin Padang

\begin{tabular}{lcccc}
\hline \multicolumn{1}{c}{ Karakteristik } & \multicolumn{2}{c}{ Malaria vivax } & \multicolumn{2}{c}{ Malaria } \\
& & \multicolumn{3}{c}{ falciparum } \\
\cline { 2 - 5 } & $\mathbf{n}$ & $\%$ & $\mathbf{n}$ & $\%$ \\
\hline $\begin{array}{l}\text { Hemoglobin } \\
\text { Normal }\end{array}$ & 18 & 56,3 & 0 & 0 \\
$(13-12 \mathrm{~g} / \mathrm{dl})$ & & & & \\
Anemia ringan & 11 & 34,4 & 1 & 100 \\
$(12,9 / 11,9-11 \mathrm{~g} / \mathrm{dl})$ & & & & \\
Anemia sedang & 3 & 9,4 & 0 & 0 \\
$\begin{array}{l}10,9-8 \mathrm{~g} / \mathrm{dl}) \\
\text { Anemia berat }\end{array}$ & 0 & 0 & 0 & 0 \\
$(<8 \mathrm{~g} / \mathrm{dl})$ & & & & \\
Leukosit & & & & \\
$<5.000 \mathrm{sel} / \mu \mathrm{l}$ & 3 & 9,4 & 1 & 100 \\
$5.000-10.000 \mathrm{sel} / \mu \mathrm{l}$ & 22 & 68,8 & 0 & 0 \\
$>10.000 \mathrm{sel} / \mu \mathrm{l}$ & 7 & 21,9 & 0 & 0 \\
Trombosit & & & & \\
$<150.000 \mathrm{sel} / \mu \mathrm{l}$ & 11 & 34,4 & 0 & 0 \\
$150.000-450.000$ & 21 & 65,6 & 1 & 100 \\
sel $/ \mu \mathrm{l}$ & & & & 0 \\
$>450.000 \mathrm{sel} / \mu \mathrm{l}$ & 0 & 0 & 0 & 0 \\
\hline
\end{tabular}

Tabel 3 menggambarkan bahwa dari 32 orang pasien malaria vivax, terdapat 18 orang (56,3\%) memiliki kadar hemoglobin dalam batas normal, 11 orang $(34,4 \%)$ mengalami anemia ringan, dan 3 orang 
$(9,4 \%)$ mengalami anemia sedang. Pasien malaria vivax yang memiliki jumlah leukosit dalam batas normal didapatkan sebanyak 22 orang (68,8\%), 7 orang $(21,9 \%)$ mengalami leukositosis, dan 3 orang $(9,4 \%)$ mengalami leukopenia. Trombosit dengan jumlah normal pada pasien malaria vivax didapatkan sebanyak 21 orang $(65,6 \%)$ dan 11 orang (34,4\%) mengalami trombositopenia. Jumlah pasien malaria yang terinfeksi Plasmodium falciparum di RSUD Dr. Rasidin berjumlah 1 orang dengan anemia ringan, leukopenia, dan trombosit dalam jumlah normal.

Tabel 4. Karakteristik Status Hematologis Pasien Malaria Vivax dan Malaria Falciparum di RSUP Dr. M. Djamil Padang

\begin{tabular}{|c|c|c|c|c|}
\hline \multirow[t]{2}{*}{ Karakteristik } & \multicolumn{2}{|c|}{ Malaria vivax } & \multicolumn{2}{|c|}{$\begin{array}{c}\text { Malaria } \\
\text { falciparum }\end{array}$} \\
\hline & $\mathbf{n}$ & $\%$ & $\mathbf{n}$ & $\%$ \\
\hline \multicolumn{5}{|l|}{ Hemoglobin } \\
\hline $\begin{array}{l}\text { Normal } \\
(13-12 \mathrm{~g} / \mathrm{dl})\end{array}$ & 8 & 42,1 & 0 & 0 \\
\hline $\begin{array}{l}\text { Anemia ringan } \\
(12,9 / 11,9-11 \mathrm{~g} / \mathrm{dl})\end{array}$ & 7 & 36,8 & 1 & 14,3 \\
\hline $\begin{array}{l}\text { Anemia sedang } \\
(10,9-8 \mathrm{~g} / \mathrm{dl})\end{array}$ & 4 & 21,1 & 5 & 71,4 \\
\hline $\begin{array}{l}\text { Anemia berat } \\
(<8 \mathrm{~g} / \mathrm{dl})\end{array}$ & 0 & 0 & 1 & 14,3 \\
\hline Leukosit & & & & \\
\hline$<5.000 \mathrm{sel} / \mu \mathrm{l}$ & 1 & 5,3 & 4 & 57,1 \\
\hline $5.000-10.000 \mathrm{sel} / \mu \mathrm{l}$ & 9 & 47,4 & 0 & 0 \\
\hline$>10.000 \mathrm{sel} / \mu \mathrm{l}$ & 9 & 47,4 & 3 & 42,9 \\
\hline Trombosit & & & & \\
\hline$<150.000 \mathrm{sel} / \mu \mathrm{l}$ & 5 & 26,3 & 5 & 71,4 \\
\hline $\begin{array}{l}150.000-450.000 \\
\mathrm{sel} / \mu \mathrm{l}\end{array}$ & 14 & 73,7 & 2 & 28,6 \\
\hline$>450.000 \mathrm{sel} / \mu \mathrm{l}$ & 0 & 0 & 0 & 0 \\
\hline
\end{tabular}

Tabel 4 menggambarkan bahwa dari 19 orang pasien malaria vivax, terdapat 8 orang $(42,1 \%)$ memiliki kadar hemoglobin dalam batas normal, 7 orang $(36,8 \%)$ mengalami anemia ringan, dan 4 orang $(21,1 \%)$ mengalami anemia sedang. Pasien malaria vivax yang memiliki jumlah leukosit dalam batas normal didapatkan sebanyak 9 orang (47,4\%), 9 orang $(47,4 \%)$ mengalami leukositosis, dan 1 orang (5,3\%) mengalami leukopenia. Trombosit dengan jumlah normal pada pasien malaria vivax didapatkan sebanyak 14 orang $(73,7 \%)$ dan 5 orang $(26,3 \%)$ mengalami trombositopenia. Jumlah pasien malaria yang terinfeksi Plasmodium falciparum di RSUP Dr. M. Djamil berjumlah 7 orang dengan 1 orang (14,3\%) mengalami anemia ringan, 5 orang $(71,4 \%)$ anemia sedang, dan 1 orang (14,3\%) mengalami anemia berat. Pasien malaria falciparum yang mengalami leukopenia sebanyak 4 orang $(57,1 \%)$ dan 3 orang (42,9\%) mengalami leukositosis. Trombosit dalam jumlah normal ditemukan pada 2 orang (28,6\%) pasien malaria falciparum dan 5 orang $(71,4 \%)$ lainnya mengalami trombositopenia.

\section{Gambaran Status Hematologis Pasien Malaria Falciparum dan Malaria Vivax}

Tabel 5. Gambaran status hematologis pada pasien malaria falciparum dan malaria vivax

\begin{tabular}{llll}
\hline \multicolumn{1}{c}{ Status Hematologis } & $\begin{array}{c}\text { Malaria } \\
\text { falciparum } \\
(\mathrm{n}=8)\end{array}$ & \multicolumn{1}{c}{$\begin{array}{c}\text { Malaria } \\
\text { vivax }(\mathrm{n}=51)\end{array}$} \\
\hline Kadar & Rerata \pm & $10,00 \pm$ & $12,38 \pm 1,59$ \\
Hemoglobin & SD & 2,06 & \\
Jumlah & Rerata \pm & $8267 \pm$ & $9017 \pm 4588$ \\
Leukosit & SD & 6431 & \\
Jumlah & Rerata \pm & $161.250 \pm$ & $208.254 \pm$ \\
Trombosit & SD & 79.618 & 107.635 \\
\hline
\end{tabular}

Tabel 5 menunjukkan kadar hemoglobin ratarata pada pasien malaria falciparum adalah 10,00 \pm $2,06 \mathrm{~g} / \mathrm{dl}$. Jumlah rata-rata leukosit adalah $8267 \pm$ $6431 \mathrm{sel} / \mu \mathrm{l}$ dan jumlah rata-rata trombosit adalah $161.250 \pm 79.618 \mathrm{sel} / \mu \mathrm{l}$. Pasien malaria vivax memiliki nilai hemoglobin rata-rata $12,38 \pm 1,59 \mathrm{~g} / \mathrm{dl}$. Jumlah rata-rata leukosit adalah $9017 \pm 4588 \mathrm{sel} / \mu \mathrm{l}$ dan jumlah rata-rata trombosit adalah $208.254 \pm 107.635$ $\mathrm{sel} / \mu \mathrm{l}$.

\section{Perbandingan Kadar Hemoglobin Pada Pasien Malaria Falciparum dan Malaria Vivax}

Tabel 6. Perbandingan Kadar Hemoglobin Pada Pasien Malaria Falciparum dan Malaria Vivax

\begin{tabular}{llll}
\hline $\begin{array}{c}\text { Status } \\
\text { Hematologis }\end{array}$ & \multicolumn{1}{c}{$\begin{array}{c}\text { Jenis } \\
\text { Malaria }\end{array}$} & Rerata \pm SD & p \\
\hline Kadar & Malaria & $10,00 \pm 2,06$ & 0,000 \\
Hemoglobin & falciparum & & \\
& Malaria & $12,38 \pm 1,59$ & \\
& vivax & & \\
& & & \\
\hline
\end{tabular}


Tabel 6 menggambarkan nilai rata-rata hemoglobin pada pasien malaria falciparum yaitu $10,00 \pm 2,06$, lebih rendah dibandingkan nilai hemoglobin rata-rata pasien malaria vivax yaitu 12,38 $\pm 1,59$. Analisis data dengan uji Independent t-test didapatkan nilai $p=0,000 \quad(p<0,05)$ yang berarti terdapat perbedaan yang bermakna antara nilai ratarata hemoglobin malaria falciparum dan malaria vivax.

\section{Perbandingan Jumlah Leukosit Pada Pasien Malaria Falciparum dan Malaria Vivax}

Tabel 7. Perbandingan jumlah leukosit pada pasien malaria falciparum dan malaria vivax

\begin{tabular}{lllc}
\hline $\begin{array}{c}\text { Status } \\
\text { Hematologis }\end{array}$ & \multicolumn{1}{c}{$\begin{array}{c}\text { Jenis } \\
\text { Malaria }\end{array}$} & Rerata \pm SD & p \\
\hline Jumlah & Malaria & $8267 \pm 6431$ & 0,198 \\
Leukosit & falciparum & & \\
& Malaria & $9017 \pm 4588$ & \\
& vivax & & \\
& & & \\
&
\end{tabular}

Tabel 7 menunjukkan bahwa jumlah rata-rata leukosit pada pasien malaria falciparum yaitu $8267 \pm$ 6431, lebih rendah dibandingkan jumlah rata-rata leukosit pada pasien malaria vivax yaitu $9017 \pm 4588$. Hasil analisis data dengan uji Independent t-test didapatkan nilai $p=0,198$ ( $p>0,05)$ berarti tidak terdapat perbedaan yang bermakna antara jumlah rata-rata leukosit pada pasien malaria falciparum dan malaria vivax.

Perbandingan Jumlah Trombosit Pada Pasien Malaria Falciparum dan Malaria Vivax

Tabel 8. Perbandingan jumlah trombosit pada pasien malaria falciparum dan malaria vivax

\begin{tabular}{llll}
\hline $\begin{array}{c}\text { Status } \\
\text { Hematologis }\end{array}$ & \multicolumn{1}{c}{$\begin{array}{c}\text { Jenis } \\
\text { Malaria }\end{array}$} & Rerata \pm SD & p \\
\hline Jumlah & Malaria & $161.250 \pm$ & 0,242 \\
Trombosit & falciparum & 79.618 & \\
& Malaria & $208.254 \pm$ & \\
& vivax & 107.635 & \\
\hline
\end{tabular}

Tabel 8 menggambarkan jumlah rata-rata trombosit pada pasien malaria falciparum yaitu $161.250 \pm 79.618$, lebih rendah dibandingkan jumlah rata-rata trombosit pada pasien malaria vivax yaitu 208.254 \pm 107.635. Hasil analisis data dengan menggunakan uji independent t-test didapatkan nilai $p=0,242 \quad(p>0,05)$ yang berarti tidak terdapat perbedaan yang bermakna antara jumlah rata-rata trombosit pada pasien malaria falciparum dan malaria vivax.

\section{PEMBAHASAN}

Karakteristik Responden Berdasarkan Usia, Jenis Kelamin, dan Spesies Penyebab

Berdasarkan hasil penelitian pada pasien malaria di bagian rawat inap IImu Penyakit Dalam RSUD Dr. Rasidin Padang tahun 2015 - 2017 (Tabel 1), diketahui bahwa pasien dengan jenis kelamin perempuan $(51,5 \%)$ lebih banyak dibandingkan lakilaki (48,5\%). Penularan pada pasien dengan jenis kelamin perempuan dikaitkan dengan mobilitas yang rendah sehingga lebih besar kemungkinan untuk terpapar dengan vektor malaria atau lokasi rumah yang berada dekat dengan tempat perkembangbiakan vektor. ${ }^{13}$

Berbeda dengan hasil penelitian yang didapatkan di RSUD Dr. Rasidin, pasien malaria terbanyak di RSUP Dr. M. Djamil adalah pasien yang memiliki jenis kelamin laki-laki (59,3\%). Hasil penelitian ini sejalan dengan penelitian yang dilakukan oleh Mareza Dwithania et al di Puskesmas Durian dan Talawi, Sawahlunto tahun 2013 mendapatkan hasil yang sama dimana penderita malaria didominasi oleh jenis kelamin laki-laki sebanyak $53,85 \%$, sedangkan pada perempuan sebanyak $46,15 \% .{ }^{14}$ Laki-laki lebih memungkinkan berisiko terkena malaria diakibatkan aktivitasnya yang lebih banyak di luar rumah, pekerjaan bertani, berternak, mengelola tambak yang merupakan habitat nyamuk vektor, dan budaya setempat keluar rumah pada malam hari. ${ }^{15}$

Tabel 1 menunjukkan bahwa pasien malaria terbanyak di RSUD Dr. Rasidin berada pada rentang usia 15-25 tahun (25\%). Hasil penelitian ini sesuai dengan penelitian yang dilakukan oleh Swati Aundhakar et al di India tahun 2017 yang menyatakan bahwa malaria paling banyak menginfeksi usia produktif (18-30 tahun) sebanyak 38\%. ${ }^{16}$ Pasien malaria terbanyak di RSUP Dr. M. Djamil berdasarkan Tabel 2 adalah usia 26-35 tahun (33,3\%). Hasil 
penelitian ini sejalan dengan analisis data Riskesdas 2013 yang menunjukkan bahwa umur 25-34 tahun merupakan rentang umur paling beresiko terinfeksi malaria. ${ }^{15}$ Usia 15-35 tahun termasuk usia produktif. Hasil ini berkaitan dengan usia produktif yang merupakan usia yang aktif untuk berpindah-pindah tempat kerja atau berpergian ke daerah endemis malaria sehingga kemungkinan terinfeksi malaria melalui gigitan nyamuk Anopheles sp lebih besar risikonya. ${ }^{17}$

Hasil dari Tabel 1 menunjukkan pasien malaria yang dirawat di RSUD Dr. Rasidin Padang hampir keseluruhnya disebabkan oleh $P$. vivax (97\%), hanya satu pasien yang terinfeksi $P$. falciparum (3\%). Kota Padang merupakan daerah non endemik malaria sehingga pasien malaria yang berdomisili di kota Padang hampir semuanya terinfeksi oleh $P$. vivax. Hasil ini sejalan dengan penelitian tentang epidemiologi malaria di daerah endemik yang dilakukan oleh Beatrice Autino et al pada tahun 2012 didapatkan sebanyak $57,1 \%$ orang yang terpajan infeksi $P$. vivax tinggal di daerah malaria yang tidak stabil. ${ }^{18} P$. falciparum umumnya ditemukan di daerah endemik malaria atau daerah dengan penularan malaria stabil. ${ }^{19}$ Spesies $P$. falciparum lebih banyak jumlahya ditemukan di RSUP Dr. M. Djamil dibandingkan RSUD Dr. Rasidin Padang. Tabel 1 menggambarkan bahwa spesies Plasmodium terbanyak yang menjadi penyebab malaria di RSUP Dr. M. Djamil dan RSUD Dr. Rasidin Padang adalah $P$. vivax. Hasil penelitian ini sama dengan penelitian yang dilakukan oleh Dwithania et al di Puskesmas Sungai Durian dan Talawi Sawahlunto pada tahun 2013 didapatkan spesies $P$. vivax lebih banyak menyebabkan infeksi malaria sebesar 76,92\% dibandingkan $P$. falciparum sebesar $15,38 \%{ }^{14}$

\section{Karakteristik Status Hematologis Pasien Malaria Vivax dan Malaria Falciparum}

Tabel 3 menunjukan bahwa pada pasien malaria vivax di RSUD Dr. Rasidin terdapat 14 orang yang mengalami anemia (11 orang anemia ringan dan 3 orang anemia sedang), 3 orang $(9,4 \%)$ mengalami leukopenia, 7 orang $(21,9 \%)$ mengalami leukositosis, dan 11 orang $(34,4 \%)$ mengalami trombositopenia. Pasien malaria falciparum terdapat satu orang yang mengalami anemia ringan dan leukopenia.

Tabel 4 menggambarkan bahwa pada pasien malaria vivax di RSUP Dr. M. Djamil didapatkan 11 orang mengalami anemia (7 orang anemia ringan dan 4 orang anemia sedang), 1 orang mengalami leukopenia, 9 orang mengalami leukositosis, dan 5 orang trombositopenia. Pasien malaria falciparum berjumlah 7 orang dengan 1 orang anemia ringan, 5 orang anemia sedang, 1 orang anemia berat, 4 orang leukopenia $(57,1 \%), 3$ orang leukositosis $(42,9 \%)$, dan 5 orang trombositopenia $(71,4 \%)$.

Penurunan kadar hemoglobin dan jumlah trombosit pada pasien malaria di RSUP Dr. M. Djamil lebih rendah dibandingkan pasien malaria di RSUD Dr. Rasidin Padang. Peningkatan jumlah leukosit lebih besar pada pasien malaria di RSUP Dr. M. Djamil dibandingkan pasien malaria di RSUD Dr. Rasidin Padang. Hasil ini sejalan dengan penelitian yang dilakukan oleh Das et al bahwa penurunan kadar hemoglobin, jumlah trombosit, dan peningkatan jumlah leukosit lebih banyak persentasenya terjadi pada pasien malaria yang memiliki komplikasi. ${ }^{19}$

\section{Gambaran Status Hematologis Pasien Malaria Falciparum dan Malaria Vivax}

Tabel 5 menunjukkan bahwa berdasarkan nilai rata-rata status hematologis tidak terdapat leukopenia, leukositosis, dan trombositopenia pada pasien malaria falciparum. Jumlah leukosit rerata berada pada batas normal yaitu $5.000-10.000 \mathrm{sel} / \mu \mathrm{l}$ dan jumlah trombosit rerata berada pada batas normal yaitu 150.000 $450.000 \mathrm{sel} / \mu \mathrm{l}$. Jika dilihat dari karakteristik hematologis pada masing-masing pasien masih terdapat anemia, leukopenia, leukositosis, dan trombositopenia. Hasil ini sesuai dengan teori bahwa ketika parasit menginfeksi eritrosit maka akan terjadi penghancuran eritrosit dan menstimulasi monosit dan makrofag untuk menghasilkan sitokin seperti IL-12, yang juga akan mengaktivasi sel Th1 sehingga terjadi perubahan terhadap jumlah leukosit. ${ }^{20}$

Nilai hemoglobin rerata berada pada anemia ringan- sedang pada pasien malaria falciparum. Menurut penelitian Susilawati et al pada tahun 2013 
didapatkan nilai rerata hemoglobin pada $P$. falciparum adalah $10,51 \mathrm{~g} / \mathrm{dl}^{21}$

Tabel 5 menggambarkan bahwa berdasarkan nilai rata-rata status hematologis tidak terdapat anemia , leukositosis, leukopenia, dan trombositopenia pada pasien malaria vivax. Nilai hemoglobin rerata berada pada batas normal. Jumlah leukosit rerata berada pada batas normal yaitu $5.000-10.000 \mathrm{sel} / \mu \mathrm{l}$ dan jumlah trombosit rata-rata berada pada batas normal yaitu 150.000-450.000 sel/ $\mu \mathrm{l}$. Jika dilihat dari karakteristik hematologis pada masing-masing pasien, masih terdapat anemia, leukopenia, leukositosis, dan trombositopenia. Hasil ini juga sesuai dengan teori bahwa anemia terutama tampak jelas pada malaria falciparum dan malaria kronis dengan penghancuran eritrosit yang cepat dan hebat. ${ }^{1}$

\section{Perbandingan Kadar Hemoglobin pada Pasien Malaria Falciparum dan Malaria Vivax}

Hasil dari Tabel 6 didapatkan kadar rerata hemoglobin pada pasien malaria falciparum $(10,00$ $\mathrm{g} / \mathrm{dl})$ lebih rendah dibandingkan malaria vivax (12,38 $\mathrm{g} / \mathrm{dl}$ ). Hasil ini sejalan dengan penelitian yang dilakukan oleh Susilawati et al tahun 2013 bahwa rerata kadar hemoglobin yang terinfeksi $P$. falciparum $(10,51 \mathrm{~g} / \mathrm{dl})$ lebih rendah daripada rerata kadar hemoglobin pasien terinfeksi $P$. $\operatorname{vivax}(12,22 \mathrm{~g} / \mathrm{dl}){ }^{21}$ Hasil penelitian ini didapatkan perbedaan yang bermakna antara kadar rerata kadar hemoglobin pada pasien malaria falciparum dan malaria vivax.

Penurunan kadar hemoglobin pada malaria yang disebabkan oleh $P$. falciparum lebih besar dibandingkan Plasmodium lainnya. Hal ini sesuai dengan teori bahwa $P$. falciparum menginfeksi semua jenis eritrosit (eritrosit muda dan tua) sehingga anemia dapat terjadi pada infeksi akut dan kronik. $P$. vivax dan $P$. ovale hanya menginfeksi eritrosit muda $(2 \%$ dari total eritrosit), dan $P$. malariae menginfeksi eritrosit tua (1\% dari total eritrosit) sehingga anemia baru terjadi pada infeksi ketiga spesies tersebut jika infeksinya berlangsung kronik. ${ }^{22}$

$P$. falciparum dapat membentuk knob (penonjolan) pada permukaan membran eritrositnya. Knob ini penting dalam proses sitoadherensi dan roset. Sitoadherensi adalah perlekatan antara Eritrosit yang Berparasit (EP) stadium matur dengan reseptor di permukaan endotel vaskuler, sedangkan roset adalah berkelompoknya eritrosit yang mengandung parasit (EP) dikelilingi eritrosit tidak berparasit. Roset menyebabkan obstruksi aliran darah lokal sehingga mempermudah terjadinya sitoadheren. Sitoadheren menyebabkan EP matur tidak beredar kembali dalam sirkulasi, melainkan tetap tinggal dalam jaringan mikrovaskular yang disebut EP matur mengalami sekuestrasi. Proses inilah yang berperan dalam patologi malaria berat, salah satunya anemia berat yang dapat terjadi pada infeksi $P$. falciparum. ${ }^{10}$

Eritrosit yang terinfeksi bila pecah maka akan menyebabkan hemolisis dan merozoit yang keluar dari eritrosit akan melepaskan toksin malaria berupa Glikosil Phosfatidil Inositol (GPI) yang merangsang pelepasan berbagai sitokin, salah satunya Tumor Necrosis Factor-alfa (TNF- $\alpha){ }^{10}$ TNF- $\alpha$ ini akan menyebabkan proses eritropoesis tidak efektif akibatnya dapat terjadi anemia. Faktor lain penyebab terjadinya anemia pada malaria adalah penurunan deformabilitas eritrosit dan splenic phagocytosis sehingga eritrosit mengalami peningkatan clearance dari sirkulasi. ${ }^{12}$

\section{Perbandingan Jumlah Leukosit Pada Pasien Malaria Falciparum dan Malaria Vivax}

Hasil dari Tabel 7 didapatkan jumlah rata-rata leukosit pada pasien malaria falciparum lebih rendah daripada malaria vivax, tetapi masih dalam batas normal. Hal ini sejalan dengan penelitian yang dilakukan oleh Tangpukdee et al pada tahun 2008 bahwa jumlah hitung leukosit pada pasien malaria falciparum lebih rendah daripada malaria vivax. ${ }^{23}$ Hasil penelitian ini didapatkan perbedaan yang tidak bermakna antara jumlah rata-rata leukosit pada pasien malaria falciparum dan malaria vivax. Hasil ini sesuai dengan penelitian yang dilakukan Castano et al pada tahun 2015 bahwa tidak terdapat perbedaan yang signifikan antara hitung leukosit pada pasien malaria falciparum dan malaria vivax. ${ }^{24}$

Beberapa teori menjelaskan perubahan leukosit pada malaria, diantaranya penekanan sumsum tulang sekunder akibat ketidakseimbangan respon imun, 
umur sel rata-rata yang menjadi lebih pendek, dan redistribusi leukosit ke organ limfoid dan jaringan dengan peningkatan respon inflamasi atau sekuesterasi pada mikrovaskuler. ${ }^{24}$

Leukopenia dapat terjadi pada infeksi $P$. falciparum maupun $P$. vivax. Penelitian yang dilakukan oleh Castano et al didapatkan bahwa leukopenia lebih sering terjadi pada malaria daripada leukositosis. ${ }^{24}$ Leukopenia pada malaria disebabkan oleh interaksi dari berbagai peristiwa, diantaranya sekuestrasi dari leukosit yang menyebabkan penurunan jumlah leukosit dan Glikosil Phosfatidil Inositol (GPI) merupakan antigen bersifat imunogenik yang dapat merangsang produksi sitokin proinflamasi pada monosit dan makrofag untuk meningkatkan fagositosis pada sel debris, leukosit, dan eritrosit. Peningkatan sitokin proinflamasi terutama TNF- $\alpha$ dapat menyebabkan penekanan hemopoesis dan dishemopoesis. ${ }^{23,24}$

Leukositosis terjadi terutama karena peningkatan jumlah sel Polimorfonuklear (PMN), walaupun bisa juga akibat peningkatan sel limfosit dan monosit. ${ }^{23,24}$ Studi tentang komposisi seluler sumsum tulang belakang menyimpulkan bahwa selama infeksi Plasmodium terjadi penurunan beberapa prekursor inti dan cadangan PMN dengan peningkatan sel PMN yang tidak matur di sirkulasi. Rangsangan awal dari infeksi pada cadangan dan peningkatan waktu paruh sirkulasi PMN menyebabkan leukositosis sementara. Pada malaria falciparum, leukositosis terjadi karena rangsangan dari infeksi dan peningkatan sitokin pro inflamasi ke sumsum tulang belakang untuk melepaskan leukosit selama serangan demam yang hilang timbul (paroksismal). ${ }^{24}$ Leukositosis menggambarkan keparahan dari infeksi malaria. ${ }^{10}$

\section{Perbandingan Jumlah Trombosit Pada Pasien Malaria Falciparum dan Malaria Vivax}

Hasil dari Tabel 8 didapatkan bahwa terdapat perbedaan yang tidak bermakna antara jumah ratarata trombosit pada pasien malaria falciparum dan malaria vivax. Hasil ini sejalan dengan penelitian yang dilakukan oleh Shetty et al pada tahun 2012 bahwa tidak terdapat perbedaan signifikan antara jumlah trombosit pada malaria falciparum dan malaria vivax. ${ }^{25}$
Trombositopenia lebih umum terjadi pada $P$. falciparum daripada $P$. vivax. Menurut Diana, permukaan membran eritrosit yang terinfeksi $P$. falciparum dapat membentuk tonjolan yang disebut $k n o b$ sehingga eritrosit yang terinfeksi parasit akan mudah melekat terutama pada eritrosit sekitarnya yang tidak terinfeksi, trombosit, dan endotel kapiler. Perlekatan tersebut dapat mengakibatkan pemecahan dan penurunan jumlah trombosit sehingga dapat terjadi trombositopenia. ${ }^{10}$

IgG yang berhubungan dengan trombosit atau platelet-associated lgG (PAlgG) pada malaria menjadi meningkat dan berhubungan dengan trombositopenia. Peningkatan PAlgG juga dapat diartikan sebagai aktivasi platelet. Antibodi anti-platelet tersebut dapat mengaktivasi membran trombosit yang menyebabkan pembuangan trombosit oleh sistem retikuloendotelial (RE), terutama pada limpa. Antibodi IgG yang ditemukan pada membran trombosit juga menyebabkan gangguan agregasi trombosit dan meningkatnya penghancuran trombosit oleh makrofag. ${ }^{10}$

\section{SIMPULAN}

Pada malaria falciparum dan vivax terdapat perbedaan kadar rata-rata hemoglobin yang signifikan, sedangkan jumlah leukosit dan jumlah trombosit tidak didapatkan perbedaan yang signifikan.

\section{DAFTAR PUSTAKA}

1. Harijanto PN. Malaria. Dalam: Sudoyo AW, Setiyohadi B, Alwi I, Simadibrata, Setiati S, Syam AF, editor (penyunting). Buku ajar ilmu penyakit dalam. Ed ke-6. Jakarta: Interna Publishing; 2014.hlm. 595-610.

2. Singh B, Daneshvar C. Human infection and detection of Plasmodium knowlesi. Clin Microbiol Rev. 2013;26:165-84.

3. World Malaria Report. Global malaria programme. Geneva: WHO; 2015.

4. World Malaria Report. Global malaria programme. Geneva: WHO; 2016.

5. Ditjen Pencegahan dan Pengendalian Penyakit. 
Fakta keberhasilan pengendalian malaria. Jakarta: Kemenkes RI; 2016.

6. Dinas Kesehatan Kota (DKK) Padang. Laporan tahunan DKK Padang tahun 2015 (diakses September 2017). Tersedia dari:

file:///c:/users/hp/downloads/339547273-laporantahunan-dkk-padang-tahun-2015-edisi-2016.pdf-

7. Patel A, Jain Sudha, Patel B, Modi B Hematological changes in $P$. falciparum and $P$. vivax malaria. National J Med Res. 2013;3(2): 130-3.

8. Jafar N. Anemia di daerah endemik malaria [tesis]. Makasar: Universitas Hasanuddin; 2011.

9. Sianipar NB. Trombositopenia dan berbagai penyebabnya. CDK. 2014; 41(6): 416-21.

10. Natalia D. Peranan trombosit dalam patogenesis malaria. MKA. 2014; 37(3): 219-25.

11. Bimpong AO, McLean R, Bhonda E, Lewis SM. The use of the white cell count and haemoglobin in combination as an effective screen to predict the normality of the full blood count. Int $\mathrm{J}$ Lab Hematol. 2012; 34(1): 91-7.

12. Irawan $\mathrm{H}$, Merry MS, Wuryaningsih YNS, Baskoro T. Profil hematologik berdasarkan jenis plasmodium pada pasien malaria rawat inap di RSK Lindimara, Sumba Timur. BIK DW. 2017; 2(2): 394-401.

13. Ernawati K, Soesilo B, Duarsa A, Rifqatussa'adah. Hubungan faktor risiko individu dan lingkungan rumah dengan malaria di Punduh Pedada kabupaten Pesawaran, Lampung. MJHR. 2011; 15(2):51-7.

14. Dwithania M, Irawati N, Rasyid R. Insiden malaria di puskesmas Sungai Durian dan puskesmas Talawi kota Sawahlunto. JKA. 2013;2(2):76-9.

15. Mayasari $R$, Andriyani $D$, Sitorus $H$. Faktor risiko yang berhubungan dengan kejadian malaria di indonesia (analisis lanjut Riskesdas 2013). BPK. 2016;44(1):13-24.
16. Aundhakar S, Prajapati P, Kothia D, John D, Shrisath A, Khatri M, et al. Study of clinical and hematological profile of Plasmodium vivax malaria in a tertiary care hospital in Western Maharashtra. IJSS. 2017; 5(3): 257-60.

17. Solikhah. Pola penyebaran penyakit malaria di kecamatan Kokap, kabupaten Kulonprogo. Buletin Penelitian Sistem Kesehatan. 2012. 15(3): 213-22.

18. Autino B, Noris A, Russo R, Castelli F. Epidemiology of malaria in endemic areas. Mediterr J Hematol Infect Dis. 2012; 4(1): 60.

19. Das BP, Ganguly R, Khuntia HK, Bal M, Ranjit M. Hematological changes in severe P. falciparum malaria. Int. J. Curr. Microbiol. App. Sci. 2017; 6(6):1733-9.

20. Bratawidjaja KG, Rengganis I. Imunologi infeksi. Dalam: Imunologi Dasar. Jakarta: Balai Penerbit FK UI; 2009.hlm.441-4

21. Susilawati, Sennang N, Naid T, Attamimi F. Kadar hemoglobin dan densitas parasit pada penderita malaria di Lombok Tengah. JST Kesehatan. 2013;3(3): 298-304.

22. Bartoloni A, Zammarchi L. Clinical aspects of uncomplicated and severe malaria. Mediterr $\mathrm{J}$ Hematol Infect Dis. 2012;4(1).

23. Tangpukdee N, Wilairatana P, Yew HS, Krudsood S, Punyapradit N, Somwong W, et al. Dynamic changes in white blood cell counts in uncomplicated Plasmodium falciparum and Plasmodium vivax malaria. Elsevier. 2008: 490-4.

24. Castano AT, Echeverry EM, Arboleda AF. Leukogram profile and clinical status in vivax and falciparum malaria patients from Colombia. J Trop Med. 2015: 1-11.

25. Shetty G, Avabratha KS, Gonsalves S, Dany A, Rai BS. Thrombocytopenia in children with malaria: a study from coastal Karnataka, India. Elsevier. 2012; 2(2): 107-9. 